\begin{tabular}{|c|l|}
\hline Title & A conservational Review of Sarobetsu Mire, Northern Hokkaido \\
\hline Author(s) & Ito, Koji; Wolejko, L. \\
\hline Citation & $\begin{array}{l}\text { Environmental science, Hokkaido University : journal of the Graduate School of Environmental Science, Hokkaido } \\
\text { University, Sapporo, 13(1), 75-92 }\end{array}$ \\
\hline Issue Date & 1990-12-20 \\
\hline Doc URL & http://hdl.handle.net/2115/37258 \\
\hline Type & bulletin (article) \\
\hline File Information & 13(1)_75-92.pdf \\
\hline
\end{tabular}

Instructions for use 


\begin{tabular}{|l|l|l|l|}
\hline Environ. Sci., Hokkaido University & $13(1)$ & $75 \sim 92$ & June $\cdot 1990$ \\
\hline
\end{tabular}

\title{
A Conservational Review of Sarobetsu Mire, Northern Hokkaido
}

\author{
Koji Ito and L. Wolejko* \\ Department of Biosystem Management, Division of Environmental Conservation, \\ Graduate School of Environmental Science, Hokkaido Univerity, \\ Sapporo, 060, Japan
}

\begin{abstract}
From the point of view of conservation, the authors explained the present status of Sarobetsu Mire in relation to land use and landscape change, plant association change, and species rarity. In the land use and landscape change from 1923 to 1976 it is pointed out as follows : (1) a drastic decrease of mire, (2) an increase of cultivated land, (3) an extension of canals and road networks, and (4) short cutting of the Teshio Rever from which the enlargement of cultivated area has resulted. In the change of plant association, it is most remarkable that Sasa community has been encouraged by a decrease of soil humidity resulted from drainage. In species rarity channel digging has caused an increase of endangered species. Recently Sarobetsu Mire has been realized as a precious asset by tourists as well as inhabitants, and the authors predict that its conservational trend will be strengthened increasingly in future.
\end{abstract}

Key words : Bog, Coservation, Conservational species, Fen, Mire, Plant association, Sarobetsu, Species rarity.

\section{Introduction}

On his concluding remarks on the future of mires Goodall (1983) stated that although the existence of mires as an ecosystem is not endangered, there are areas, where the destruction of these wetlands has been almost completed. The most vulnerable are mires in areas of high civilization development, and also those formed on the border of their geographically, climatically controlled distribution (Terasmae, 1977)

In Japan, the two reasons mentioned above are combined, resulting in deterioration of mires almost everywhere in the main island of Honshu, Shikoku and Kyushu. In the lowland of Hokkaido, where conditions for extensive peat formation are the best in Japan, transformation and destruction of mires are relatively new phenomena, dating back to the beginning of this century but achieving considerable scope in the sixties. In that time large wetland-conversion scheme commenced, performed by the Hokkaido Development Agency as a national policy. Until now, more than $50 \%$ of lowland mires (of original 200,642 ha [Yano et al., 1980]) have been transformed, mostly into agricultural and urban areas (Fig. 1). There are still a considerable number of small mountain mires, both in Hokkaido and

* Present address : Agricultural College, Sczecin, Poland. 


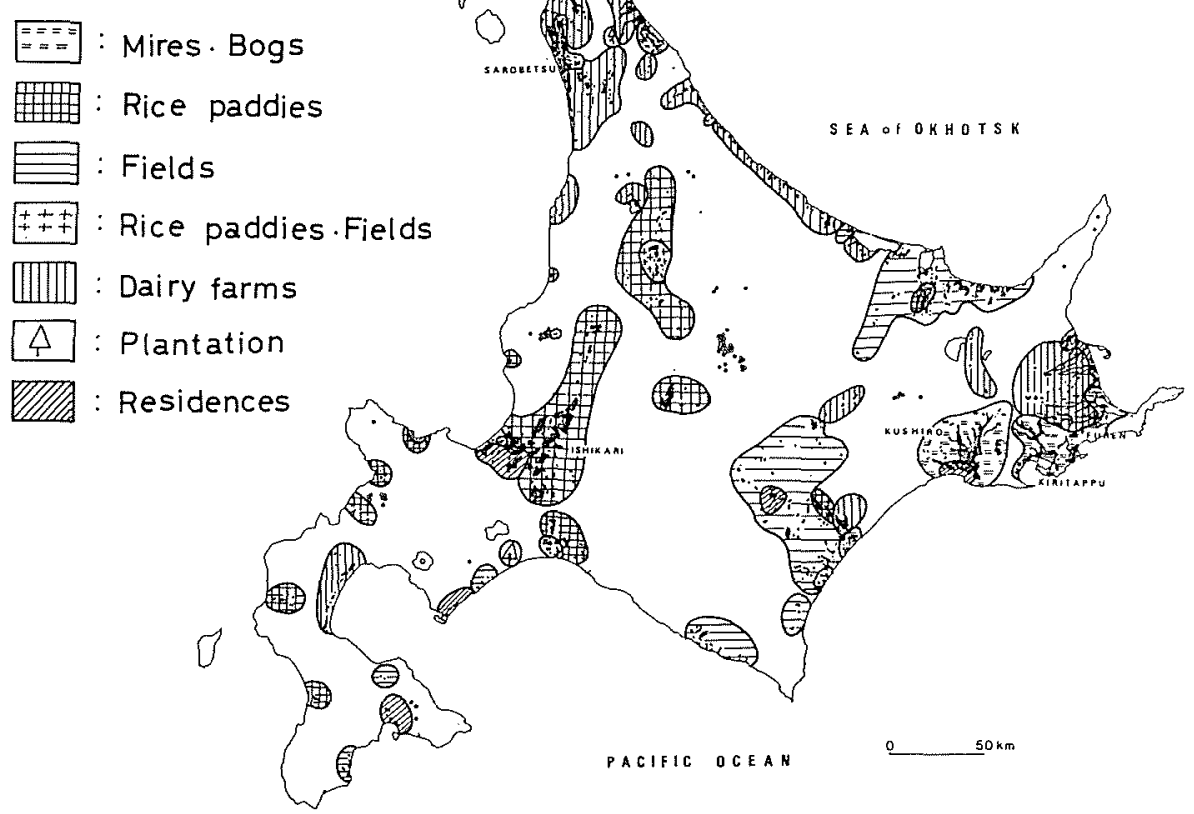

Fig. 1. Transformation of mires in Hokkaido

Northern Honshu, which are relatively safe from total destruction. In many cases, however, the interesting and rare flora and vegetation cover are affected by treading by numerous hikers and "nature loving" visitors (Kashimura and Tachibana, 1982 ; Ito, 1983 ; Ito and Tachibana, 1987 ; Tachibana, 1969, 1976, \& 1977 ; Tachibana et al. 1988).

The mire transformation processes are best studied in Hokkaido, where they are now in progress. Within the area, the degree of changes varies considerably, which can be attributed to the local differentiation of climatic conditions, accessability and distance from development centres. While the natural mire vegetation in the southern, western and northwestern parts of the island has already almost disappeared, there are still some extensive and unchanged mires in the the eastern region, namely Kushiro, Furen, and Kiritappu mires (Fig. 2). Such an inequality is well understood when the cold climate of the eastern coast, influenced by the cold Kuril Current, is compared with the milder climate of the southwestern Hokkaido. The latter, improved by the warm Tsushima Current, allows the rice cultivation on the developed surfaces of the former mires. An example of this is the case of Ishikari Plain, where about 55,00 ha of peatlands were transformed into paddy fields (Figs. 1 and 2A).

An evaluation of the relative importance of different impact types on mires in Hokkaido is given in Table 1. The biggest threat is posed by agriculture, and different forms of infrastructure development in the lowland mires.

In the present paper we deal with Sarobetsu Mire or Sarobetsu Genya as an example 


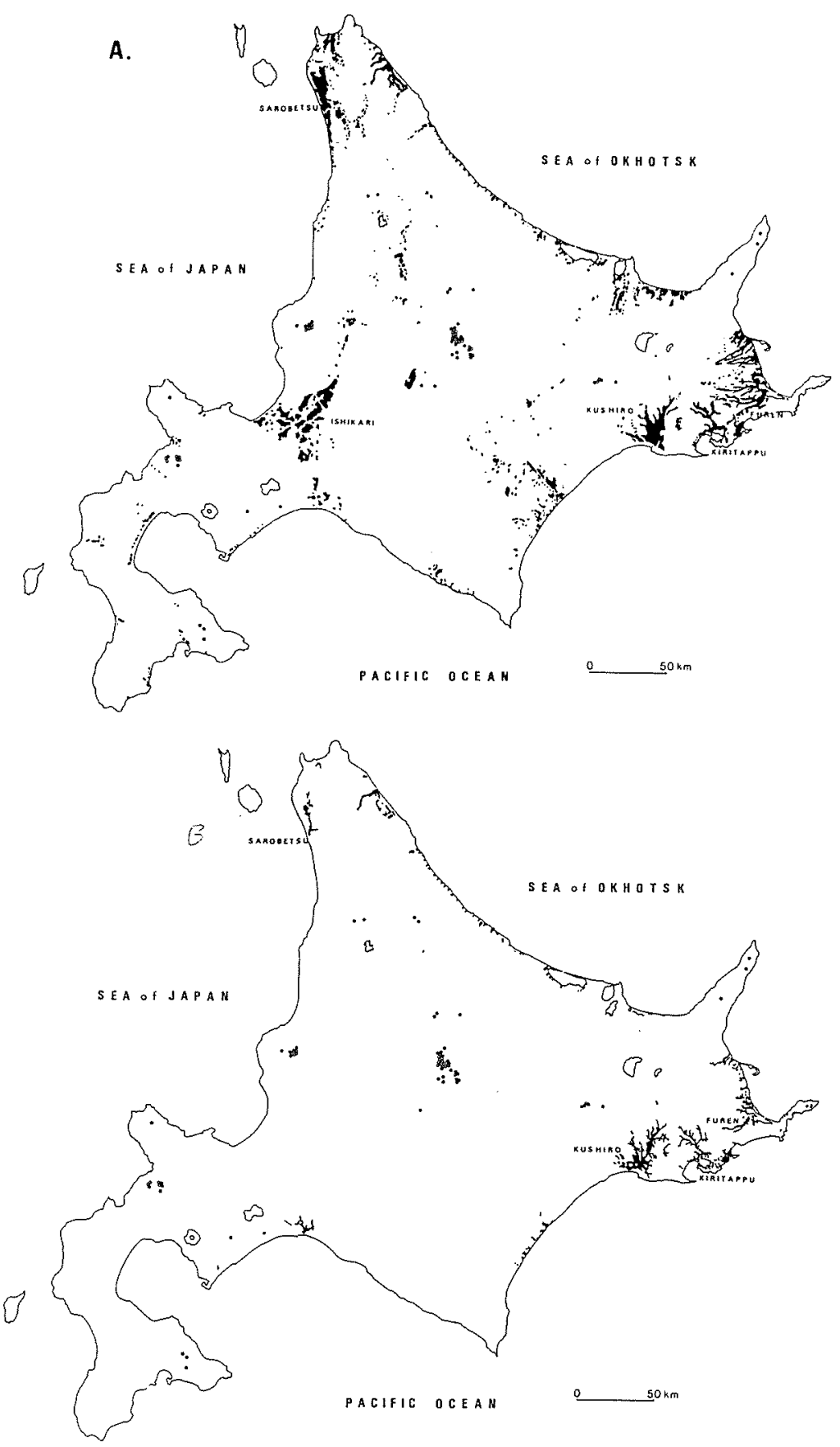

Fig. 2. Past and present distribution of mire vegetation in Hokkaido.

A. original distribution (based on the map by Hokkaido Agr. Exp.

Sta. 1936)

B. present distribution (based on by the Map Ito et al., 1982)

Black pieces : lowland mires and wetlands. Open circles : small mountain mires 
Table 1. Relative importance of different human impact types on mire ecosystem in Hokkaido.

\begin{tabular}{|c|c|c|}
\hline Type of impact & Description & $\begin{array}{l}\text { Relative importance } \\
\text { in Hokkaido }\end{array}$ \\
\hline \multicolumn{3}{|l|}{ A. Direct } \\
\hline \multicolumn{3}{|l|}{ 1. Change of function } \\
\hline a. urban development & $\begin{array}{l}\text { Occupation of mire space for construction, } \\
\text { housing, dumpt storage, sports facilities, etc. }\end{array}$ & $\mathrm{XX}$ \\
\hline $\begin{array}{l}\text { b. agricultural } \\
\text { development }\end{array}$ & $\begin{array}{l}\text { Agricultural crop production after drainage, } \\
\text { soil dressing, etc. Utilization for hay and } \\
\text { pasture. }\end{array}$ & $\mathrm{XXXX}$ \\
\hline 2. Peat cutting & Excavation and removal of peat. & $\mathrm{X}$ \\
\hline 3. Burning & Intentional or incidental fire of mire surface. & $\mathrm{XX}$ \\
\hline 4. Direct human impact & Trampling by visitors, ; plant collection. & $\mathrm{XXX}$ \\
\hline \multicolumn{3}{|l|}{ B. Indirect } \\
\hline $\begin{array}{l}\text { 5. Disturbances in } \\
\text { hydrological regime }\end{array}$ & $\begin{array}{l}\text { Change in quantity of water, fluctuations of } \\
\text { water level, ect., induced by e.g. river } \\
\text { shortcutting and embankment, ; construction of } \\
\text { roads and railways. }\end{array}$ & $\mathrm{XXX}$ \\
\hline $\begin{array}{l}\text { 6. Change of water } \\
\text { quality and nutrient } \\
\text { supply }\end{array}$ & $\begin{array}{l}\text { Eutrophication (leaching from agriculture, } \\
\text { industrial and urban pollution). } \\
\text { Acidification. }\end{array}$ & $\mathrm{XX}$ \\
\hline
\end{tabular}

$\mathrm{XXXX}$-very strong; $\mathrm{XXX}$-strong; $\mathrm{XX}$-moderate; $\mathrm{X}$-negligible

of the transformation of bog vegetation from the points of land use and landscape, plant association, and species rarity.

\section{Sarobetsu Mire or Sarobetsu Gennya}

Sarobetsu Mire lies on $45^{\circ} 05^{\prime} \mathrm{NL}$ and $141^{\circ} 40^{\prime}$ EL in the centre, NW Hokkaido, and its dimension is about 14,600 ha, $27 \mathrm{~km}$ long in $\mathrm{N}-\mathrm{S}$ direction by $5-8 \mathrm{~km}$ wide in $\mathrm{E}-\mathrm{W}$ direction. This mire belongs to a flood plain peatlands category (Sakaguchi, 1979). Mires of this type mostly originate from backmarshes of alluvial plains. Two types of the Holocene flood plain peatlands are distinguished according to the time of formation. Peat formed initially, during the major Holocene transgression, well known in Europe in the areas adjacent to sea coast, is called a basal part peat. According to Sakaguchi (op. cit) in Sarobetsu Mire the peat layer at $26 \mathrm{~m}$ below sea level is considered basal peat accumulated during the Lateglacial or the early Postglacial. Japanese basal peats are dated 8,000 to 14,000 years $\mathrm{BP}$. The second type of peatlands formed in time of sea regression and these peats are younger than 6,000 years.

The large scale alluvial plains in Japan continued to subside during the Quaternary. In the profile of Sarobetsu Mire (N-S) the floor of the peat layers becomes lower towards S, lying below the sea level in Shimosarobetsu south of Lake Penke. In this area, Carex -Sphagnum peats, which are 2-3 $\mathrm{m}$ thick in the lower half of the peat profile, lie directly on the basement of the peat layers, consisting of clay+ peat, clay, and sand (Hokkaido 

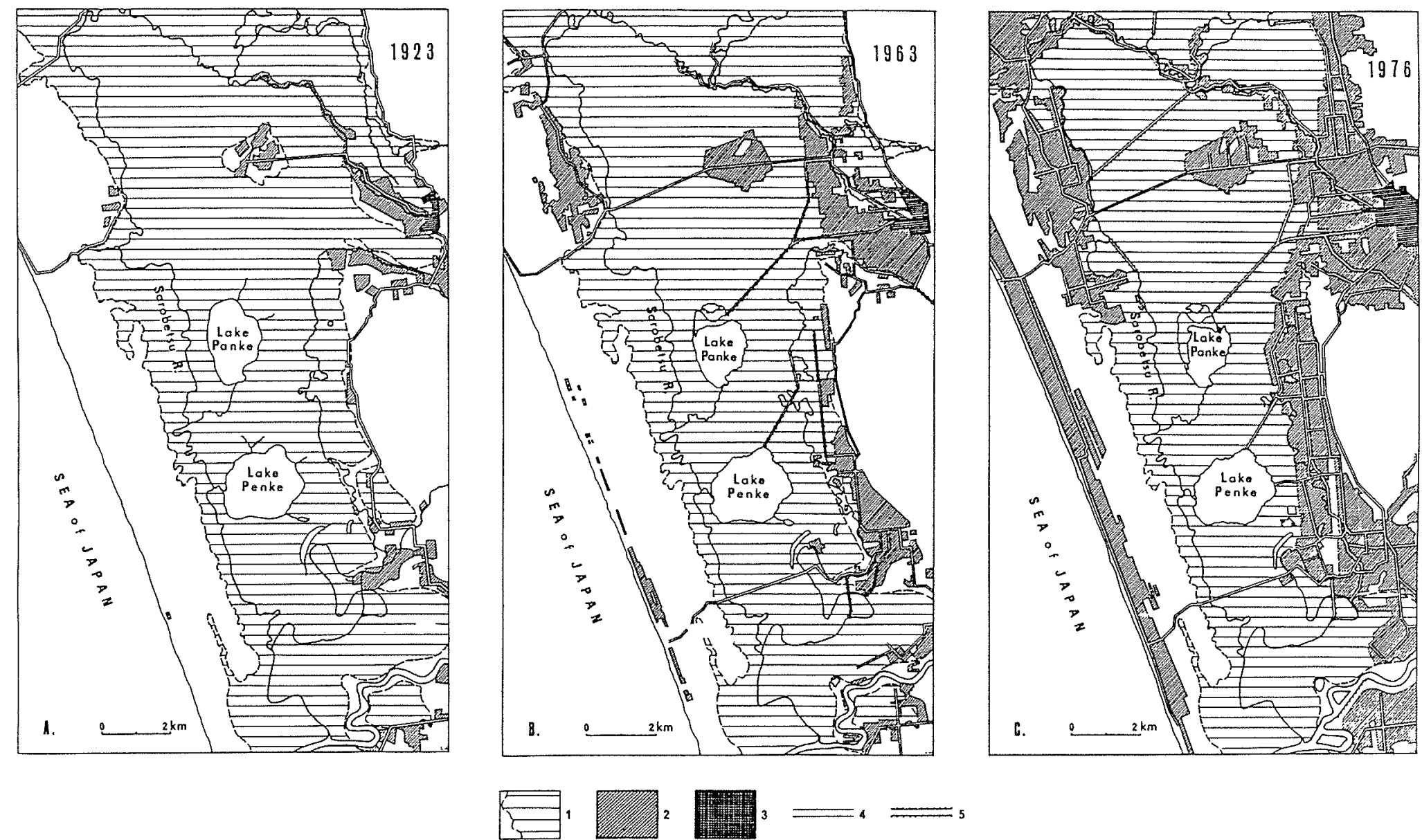

Fig. 3. Transformation of Sarobetsu Mire during 53 years A : situation in $1923 \mathrm{~B}:$ in $1963 \mathrm{C}:$ in 1976

1: mire $2:$ cultivated land $3:$ urban area $4:$ road

5 : channel 
Table 2. Area changes of mire, cultivated lands, residences and open water on Sarobetsu Mire from 1923 to 1976.

\begin{tabular}{l|r|r|r|r|r|r}
\hline & \multicolumn{2}{|c|}{ A 1923} & \multicolumn{2}{c|}{ B 1963} & \multicolumn{2}{c}{ C 1976} \\
\cline { 2 - 7 } & Area (ha) & \multicolumn{1}{c|}{$\%$} & Area (ha) & \multicolumn{1}{c|}{$\%$} & Area (ha) & $\%$ \\
\hline Mire & $12,152.70$ & $(89.1)$ & $11,411.05$ & $(81.6)$ & $9,296.69$ & $(58.0)$ \\
Cultivated lands & 806.71 & $(5.9)$ & $1,929.24$ & $(13.8)$ & $6,041.22$ & $(37.7)$ \\
Residences & 41.64 & $(0.3)$ & 86.40 & $(0.6)$ & 158.74 & $(1.0)$ \\
Open water & 637.56 & $(4.7)$ & 566.00 & $(4.0)$ & 541.02 & $(3.3)$ \\
\hline \multicolumn{1}{|c|}{ TOTAL } & $13,638.61$ & $(100.0)$ & $13,992.69$ & $(100.0)$ & 16.037 .67 & $(100.0)$ \\
\hline
\end{tabular}

Development Agency, 1963). Consequently, the basement is considered to have already become land before the occurrence of peat. The date of the emergence is considered to be 5,000-6,000 years BP. In Kamisarobetsu there are signs of the sea influence (a sand layer containing shells of Corbicula japonica has been found $1 \mathrm{~m}$ below the surface) suggesting that Sarobetsu Mire was surely affected by the subsidence centering in the southern part of the plain.

\section{Land use and landscape change}

Fig. 3 shows that during a course of (time) agricultural development, channel digging, road construction, and river regulation have progressed in Kamisarobetsu Mire. Table 2 shows area changes of mire, cultivated lands, residences, and open water on Sarobetsu Mire from 1923 to 1976. From both Fig. 3 and Table 2 it is very clear : (1) a drastic decrease of mire during 13 years from 1963 to 1976 in comparison with that of the preceding forty years from 1923 to 1963 , and the total area of mire is about $58 \%$ of the original of 1923 , (2) a similar tendency can be seen in an increase of cultivated lands; the total areas of cultivated lands in 1976 has reached six times as large as that in 1923, (3) an extension of canals and road networks along a small creek in north part of the Mire. The latter is particularly remarkable along the sea coast and eastern border of the Mire. In 1976 the northwestern part of cultivated area connects completely to the northeastern part of it and the village of Toyotomi, and (4) shortcutting of the Teshio River as seen on the right-hand bottom corner in Fig. 3. It may serve the enlargement of cultivated land in an area around this area after short-cutting construction.

Transformation of landscape is the most conspicuous feature, when large areas of diversified fen, moss and swamp forests are substituted by human-made fields and pastures. As seen in Fig. 4, vegetational landscape has diversified ; once an extensive cover of fen on the margin and moss in the centre of Sarobetsu Mire has pieced into several types of vegetation, but it is the most prominent change of landscape to be from fen to Sasa vegetation, particularly its invasion and extension along the channel for drainage. This means the progress of drying of peat lands. Moss vegetation has been shrinking its scope and is affected considerably on disappearance of Moss landscape by Sphagnum digging for soil amelioration, horticultural usage, and feed for cattle. 
Table 3. Comparative list of plant communities on Sarobetsu mire.

\begin{tabular}{|c|c|c|}
\hline \multicolumn{3}{|c|}{ Sarobetsu Mire } \\
\hline & Tachibana. H. and K. Ito (1980) & Miyawaki. A. et al. (1976) \\
\hline $\begin{array}{l}\text { A. Hydrophyte } \\
\text { Communities } \\
\text { A-I. Floating-leaf } \\
\text { Communities }\end{array}$ & $\begin{array}{l}\text { Nymphaeteum tetragonae } \\
\text { Nymphaea-Nuphar soc. } \\
\text { Nu. pumilum soc. } \\
\text { Nu.-Eleocharis soc. } \\
\text { Trapetum japonicae }\end{array}$ & \\
\hline $\begin{array}{l}\text { A-II. Emerged Plant } \\
\text { Communities }\end{array}$ & $\begin{array}{l}\text { Nu. japonicum comm. } \\
\text { Nu. japonicum soc. } \\
\text { Nu.-Sparganium soc. } \\
\text { Zizano:Phragmitetum } \\
\text { Zizania japonica soc. } \\
\text { Z.-Phragmites soc. } \\
\text { Typha-Phragmites soc. }\end{array}$ & \\
\hline $\begin{array}{l}\text { B. Marsh and Fen } \\
\text { Vegetation }\end{array}$ & $\begin{array}{l}\text { Callo-Menyanthetum triforliatae } \\
\text { Calla palustris soc. } \\
\text { Cal.-Sph. riparium soc. } \\
\text { Menyanthes-Sph. riparium soc. } \\
\text { Irs.-Sph. riparium soc. } \\
\text { Rubus-Sph. riparium soc. } \\
\text { Myrica-Sph. riparium soc. } \\
\text { Phr. commuis soc. } \\
\text { Phr.-Carex soc. } \\
\text { Phr.-Sasa soc. } \\
\text { Phr.-Moliniopsis soc. } \\
\text { Phr.-Moliniopsis-Sphagnum soc. } \\
\text { soc. } \\
\text { Carex rhynchophysa comm. } \\
\text { C. lyngbyei. comm. } \\
\text { C. koidzmii-Eriophorum gracile } \\
\text { soc. } \\
\text { Calamagrostis langsdorffii comm. } \\
\text { Calam. soc. } \\
\text { Calam. -Sasa soc. } \\
\text { Osmundastrum cinnamomeum } \\
\text { var. fokiense comm. } \\
\text { Sasa palmata comm. } \\
\text { S.-Phragmites soc. } \\
\text { S.-Moliniopsis soc. } \\
\text { S.-Malus soc. }\end{array}$ & $\begin{array}{l}\text { Sciripus-Calla palustris comm. } \\
\text { Potentilla palustris-Sph. riparium } \\
\text { comm. } \\
\text { Calam. langsdorffii-Phr. communis } \\
\text { Ass. } \\
\text { Caricetum rhynchophysae } \\
\text { S. senanensis comm. }\end{array}$ \\
\hline $\begin{array}{l}\text { C. Moss Vegitation } \\
\text { C-I. Pool and Hool- } \\
\text { low }\end{array}$ & $\begin{array}{l}\text { Caricetum limosae } \\
\text { C. limosa soc. } \\
\text { C.-Sph. apiculatum soc. } \\
\text { C.-Eriophorum gracile soc. } \\
\text { Scheuchzerio-Rhynchosporetum } \\
\text { albae boreale } \\
\text { Rhynchospora alba-Drosera } \\
\text { anglica soc. } \\
\text { Scheuchzeria-Rhynchospora } \\
\text { soc. } \\
\text { Rhy.-Sph. cuspidatum soc. } \\
\text { Rhy.-Sph. pulchrum soc. } \\
\text { Rhy.-Sph. apiculatum soc. }\end{array}$ & $\begin{array}{l}\text { Lycopodium inundatum-Drosera } \\
\text { anglica comm. } \\
\text { Sph. pulchrum comm. }\end{array}$ \\
\hline
\end{tabular}


Table 3. Comparative list of plant communities on Sarobetsu mire. (Continued)

\begin{tabular}{|c|c|c|}
\hline & Tachibana, H. and K. Ito (1980) & Miyawaki. A. et, al. (1976) \\
\hline C-II. Hummock & $\begin{array}{l}\text { Sphagnetum papillosi } \\
\text { Rhy. alba-Sphagnum papillos- } \\
\text { um soc. } \\
\text { Eleocharis margaritacea-Sph. } \\
\text { papillosum soc. } \\
\text { C. middendorffii-Sph. papillos- } \\
\text { um soc. } \\
\text { C. middendorffii-Sph. magell- } \\
\text { anicum soc. } \\
\text { Sphagnetum fusci } \\
\text { Ledum-Sph. fusum soc. } \\
\text { Empetrum-Sph. fuscum soc. } \\
\text { Polytrichum-Cladonia comm. } \\
\text { Emp.-Poytrichum soc. } \\
\text { Emp.-Cladonia soc. } \\
\text { Oxycocco-Caricetum middendor- } \\
\text { ffii } \\
\text { Vaccinium oxycoccus-Carex } \\
\text { middendorffii soc. } \\
\text { Vacc. oxycoccus-C. middendor- } \\
\text { ffii-Sph. magellanicum soc. } \\
\text { Sph. capillaceum soc. }\end{array}$ & $\begin{array}{l}\text { Rubus chamaemorus-Sph. } \\
\text { papillosum Ass. }\end{array}$ \\
\hline $\begin{array}{l}\text { C-III. Intermediate } \\
\text { (Transition) }\end{array}$ & $\begin{array}{l}\text { Moliniopsidetum japonicae } \\
\text { Moliniopsis japonica-C. midden } \\
\text { dorffii soc. } \\
\text { Mol. japonica-Myrica gale var. } \\
\text { tomentosa soc. } \\
\text { Mol. japonica-C. koidzumii soc. } \\
\text { Mol. japonica-S. palmata soc. }\end{array}$ & $\begin{array}{l}\text { Carici-Moliniopsietum japonicae } \\
\text { C. lasiocarpa var. occultans-Mol. } \\
\text { japonica comm. } \\
\text { S. senanensis-Mol. japonica comm. }\end{array}$ \\
\hline
\end{tabular}

In the table Phragmites communis is an old name of Ph. australis.

\section{Plant association change}

Phytosociologically or syntaxonomically Sarobetsu Mire is characterized by the prevalence of the Moliniopsidetum japonicae, of several elements of the Oxycocco-Caricetum middendorffii, and richness of orchidaceous plants in comparison to other mires in Hokkaido (Tachibana and Ito, 1980). Phytosociological works on Sarobetsu Mire based on the Relevé method (Ellenberg, 1955 ; Mueller-Dombois and Ellenberg, 1974) were carried out by Ito and Tohyama (1968), Ito et al. (1969), Miyawaki et al. (1976), and Tachibana and Ito (1980). Miyawaki et al. distinguished 12 vegetational units (associations and communities) under such categories as Hochmoor, Zwischenmoor, Sasa meadow, Niedermoor, swamp, marsh, and forest, and made a vegetation map (cf. Fig. 4) in their work in 1976. Tachibana and Ito described 25 associations and communities; it was the completion of preworks by Ito et al. in 1969. Their major categories are hydrophyte communities or deep marsh, fen, moss, tall herb communities, and swamp. The comparison of the two works mentioned above is shown in Table 3.

In fact, the changes of plant associations have never followed on Sarobetsu Mire. In spite of it, it is possible to detect the changes at the community level as seen in Tsujii's work, although it is partial. 


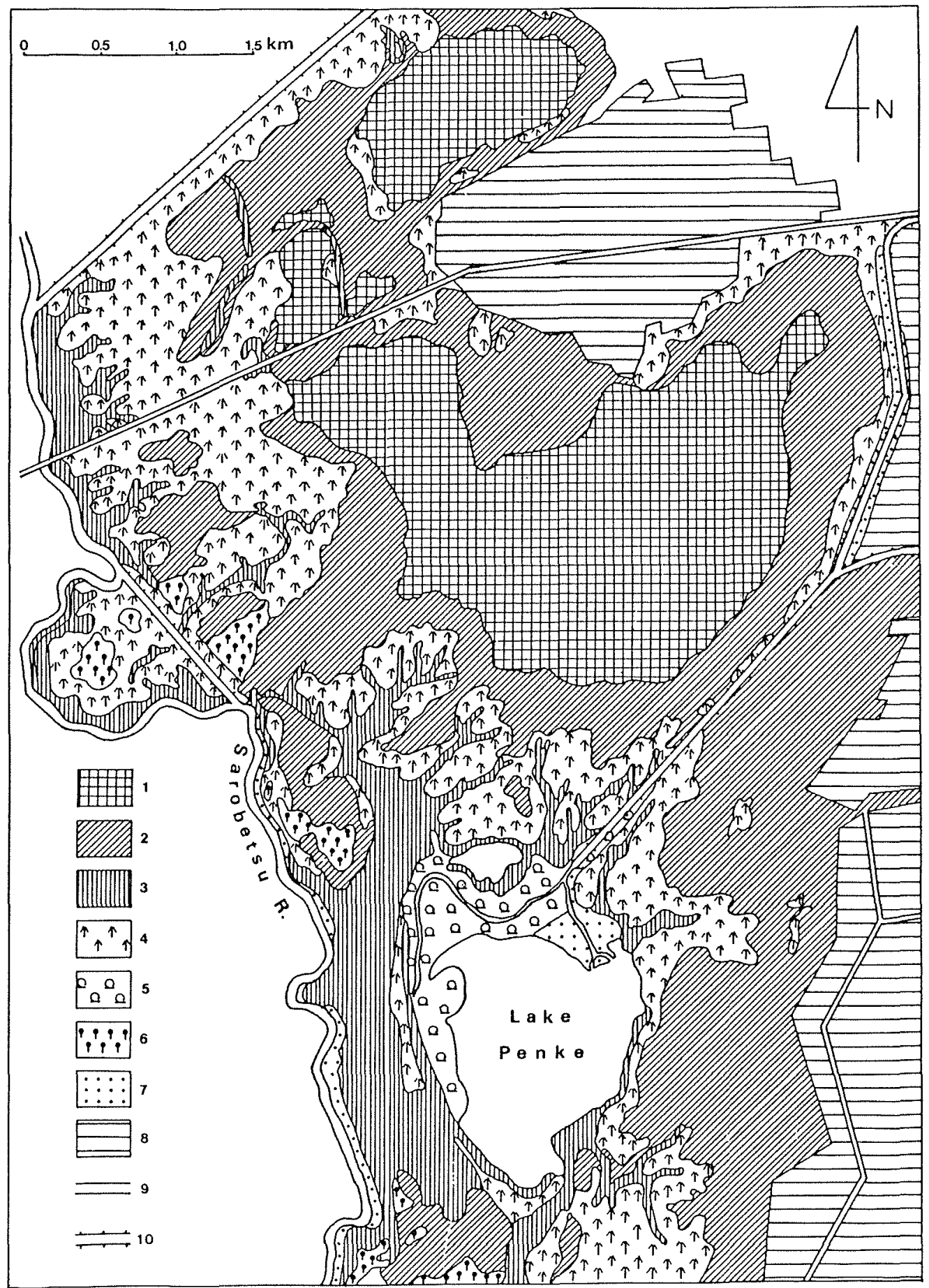

Fig. 4. vegetation map of (Kami) Sarobetsu Genya (based on the map by Miyawaki et al., 1976)

$1:$ moss $2:$ poor fen $3:$ fen $4:$ Sas $a$ thickets $5:$ willow bushes 6 : alder forests $7:$ tall herbs $8:$ pasture $9:$ roads $10:$ channels 

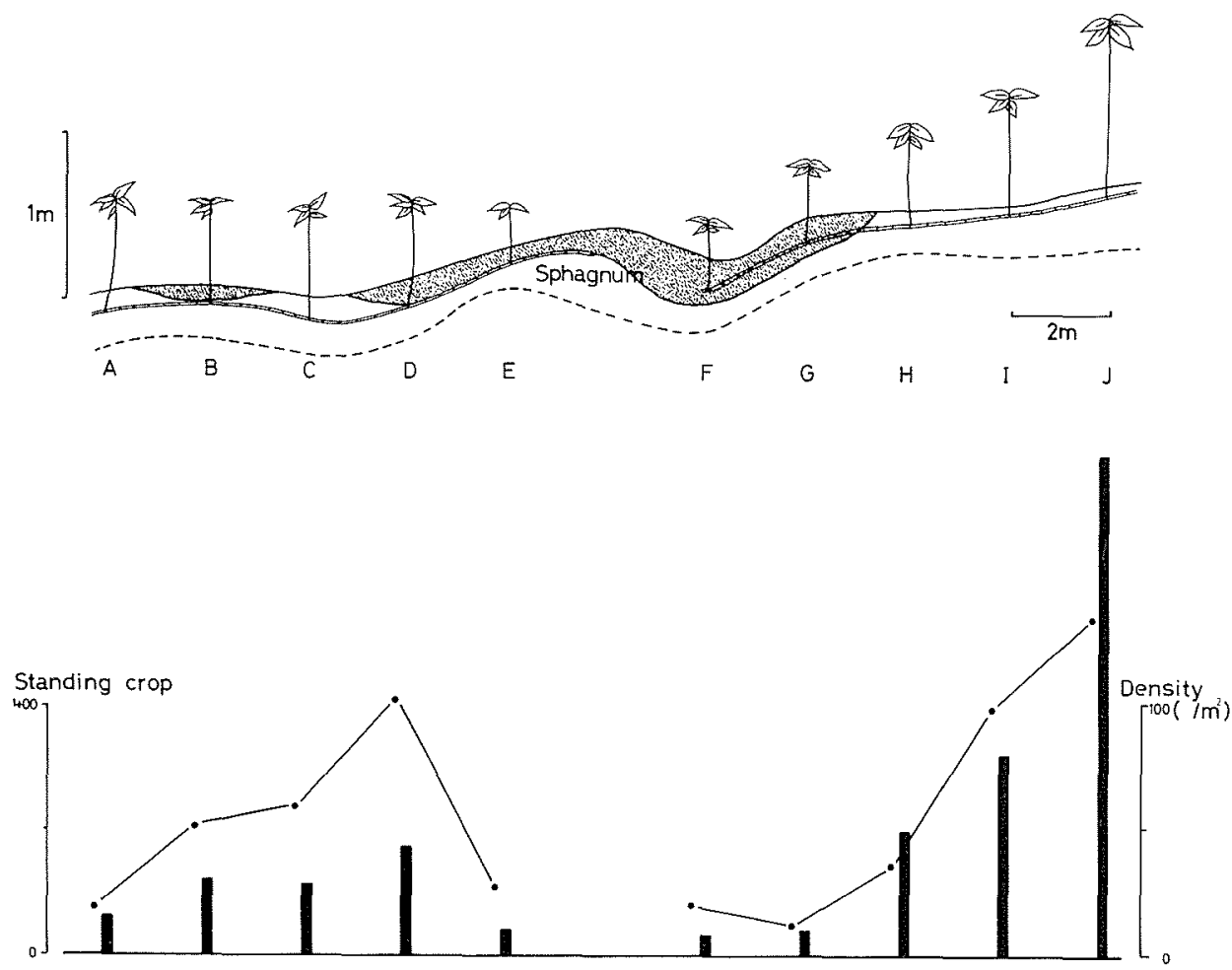

Fig. 5. A relationship between substrate humidity and Sasa growth in Tsukigako mire, Ishikari. Note that the standing crop $\left(\mathrm{g} / \mathrm{m}^{2}\right.$ ) (solid lines), culm heights (top figure) and culm desity (solid colums) decrease drastically at points E. F and $G$ which are covered with a thick Sphagnum layer (stippled areas) (Takakuwa, 1981 ; Ito, 1983 ; Takakuwa and Ito, 1986)

Beside the work mentioned already, Tsujii (1963) distinguished 7 dominant species types, although they were not based on phytosociological Releve method, but his phenotypical dominant species types are available to detect remarked changes of vegetation in a site affected by drainage or drying up of a bog. His types are as follows : (1) E type ; Empetrum nignum var. japonicum (dominant), (2) C type ; Calamagrostis langsdorffii (d.), (3) H type ; Hemerocallis esculenta (d.), (4) M type ; Myrica gale var. tomentosa (d.), (5) O Type ; Vaccinium oxycoccus (d.), (6) R type ; Rhynchospora alba (d.), and (7) S type ; Sasa palmata or S. senanensis (d.). He set 117 meshes over Sarobetsu Mire in 1960, and checked them in 1970 , ten years later. The change patterns are as follows:

$\begin{array}{ll}1960 & 1970 \\ \text { C type } & \text { S type } \\ \text { H type } & \text { S, C, and E type } \\ \text { M type } & \text { S type } \\ \text { O type } & \text { E type } \\ \text { R type } & \text { E type }\end{array}$


Here, the change to Sasa type is predominant, and it is essential to identify the true modification resulted from drainage or drying up, because it shows the lowering of ground water level, the change of physical features of soil, etc. The change to $\mathrm{E}$ type is sometimes superfluous, because the dominant Empetrum can elongate its prostrate stems and branches radiately from the centre of the stock into all direction indifferent from microhabitual features. However, the change from $\mathrm{R}$ type to $\mathrm{E}$ type is resulted from the effect of drainage on the alteration of vegetation, and means a disappearance of "Schlenke" and remarked deterioration of the vitality of $R$. alba. In addition, the area of the wettest communities with Scheuchzeria palustris has reduced its area to $50 \%$ during ten years from 1960 to 1970 (Tsujii, 1963).

Specific communities which are prosperous along ditches and channels on Sarobetsu Mire are as follows: (1) Calamagrostis langsdorffii community predominated by C. langsdorffii, and followed by Phragmites australis, Sanguisorba tenuifolia var. alba, Iris laevigata, Lycopus uniflorus, etc. ; (2) Osmundastrum cinnamomeum var. fokiense community predominated by Osm. cinn. var. fokiense, and followed by Moliniopsis japonica, Myrica gale var. tomentosa, Hemerocallis esculenta, Phr. australis, Lastrea nipponica, Sasa palmata, etc. ; and (3) Sasa palmata community dominated by $S$. palmata, and followed by Pteridium aquilinum var. latiusculum, Hem. esculenta, Mol. japonica, Polygonum perifoliatum, etc. Working agents of transformation are drainage and burning in all communities mentioned above. A close relationship between Sasa growth and ground water content is shown in Fig. 5. (cf. Ito, 1983).

\section{Species rarity}

The indigenous flora of Sarobetsu Mire is characterized by numerous rare bog plants, and by relative richness of orchids. From the 71 species of the Orchidaceae native to Hokkaido (Tatewaki, 1954), several were reported from the mire. Their survival, as well as that of other bog plants, is highly endangered by progress in drainage and disappearance of native communities. This applies to such species of bog orchids as Amitostigma kinoshitae, Habenaria yezoensis var. longicalcarata, Plathanthera tipuloides var. nipponica, Pogonia japonica, and Eleorchis japonica, among which the latter two species are on Sarobetsu Mire at their northern distributional border. The list of other endangered bog species contains Drosera anglica, Scheuchzeria palustris, and Lycopodium inundatum.

Channel digging is the most influential disturbances, allowing the advancement of Sasa community along newly-built watercourses. The replacement of a poor fen community, that is, the Moliniopsidetum japonicae, by the $S$. palmata facies is the most remarkable. The decrease in species number and almost complete disappearance of character species of the Oxycocco-Caricetum middendorffii and the Sphagnetum papillosi, and such elements of bog vegetation as Vaccinium oxycoccus, Chamaedaphne calyculata, Drosera rotundifolia, Spahgnum papillosum, Eriocaulon sp., etc. have also been reported (Tachibana and Ito, 1980).

About 20 years ago, when Ito engaged in the phytosociological work on Sarobetsu 
Mire, it was possible to recognize Picea glehnii stands in some places. This species is nearly almost endemic of Hokkaido, and prefers to establish their stands in wetlands. However, as its growth rate is very slow, and also it can tolerate severe - particularly watersaturated and wind blown- conditions, the dwarf type of this tree is the best for "Bonsai". At the present time, $P$. glehnii stands have vanished and $P$. glehnii is going to disappear from Sarobetsu Mire by drying of the bog and digging out the dwarf Picea by Bonsai-lovers.

According to the Red-data Book (Numata et al., 1989) it should be noticed : most of extinct species are in wetlands or bogs, and their extinction is resulted from the development of wetlands or bogs, that is, lowering the water table or lack of soil humidity ; on Orchidaceous species the extinction is mainly due to the habitat deterioration and too much collection of them for the appreciation and ornament commercially or personally. Orchidaceous species on Sarobetsu Mire have been endangered : one is the habitat deterioration due to the canal or channel construction, and the other is the disappearance of conifer forests, because some of them are clearly forest-dependent species.

Anyway, the development of Mire must, if unwisely, despoil all things of value in wildlife which have not been substituted.

\section{Concluding remarks}

In central and western Europe the most endangered are species of both extremely oligotrophic and highly calcareous sites (Jasnowski, 1972 ; Wolejko, 1983 ; Sheail and Wells, 1983, etc.). In Hokkaido, where the ecological gradient is not so pronounced, the oligotrophic flora is still sufficiently preserved in the mountainous areas. However, rare elements of the mesotrophic fens and bogs in lowlands are on the verge of extermination. Thus, the necessary efforts in nature protection as well as nature conservation should be oriented towards these particular types of mire systems.

The transformation of natural vegetation to cultivated fields has been rather limited, because the climatic condition is not favourable to cultivation of various kinds of crops in comparison to warmer region. The agricultural activities are not so high, but the dairy activities are high. According to the Ecosystem Map of Hokkaido (Ito et al., 1982) Sarobetsu area is one of major dairy fields in Hokkaido, and is considered to be the northern-extreme dairy farm area in Japan. However, the trend of depopulation has never stagnated, and people have been looking for a new industry.

Now, Sarobetsu Mire is included in the Rishiri-Rebun-Sarobetsu Quasi-National Park, and most of them are strictly protected by Government. Thus, Sarobetsu Mire is noticed an important resource of a sight-seeing and environmental education, and an invaluable specimen of lowland bog in Japan.

Although it is very natural that increasing development of this Mire should be stopped to prevent it from drying up, it is essential to watch closely the acceleration of eutrophication of water and pools by increase of visitors, etc. Unfortunately, we have not any data on the water chemistry of this Mire, but it is urgent to begin the water-chemical studies on the Mire as we pointed out already (Wolejko and Ito, 1986). 
There is one problem of landscape transformation. We can see a lodgehouse built for bird watching and environmental education to visitors by Environmental Agency. This building serves unfortunately a role which disturbs the eyesight. This is a wrong case in a sense of deterioration of natural landscape, because the lodge cuts endless sight - the sky line and extremely extensive landscape of plain bog vegetation. It should have been built on either end of the Mire.

The conservation of plant association is responsible for that of rare species. The conservation of Sasa community, however, is sometimes problematic. Sasa prefers dry or mesic condition to wet condition, and indicates the drying up of soils in bog vegetation. The establishment of Sasa community prevents the development of herbaceous bog communities, and reduces the diversity of species richness. In addition, the invasion of Sasa into the bog may lead to the eutrophication of oligotrophic Moss by the supply of a large amount of leaves. Thus, we are coming face to face with conservational resolution of the eutrophication of waters, drying of soils, and the reduction of the species diversity on Sarobetsu Mire.

The vast extension of bog vegetation on Sarobetsu Mire is the greatest of the lowland bog vegetations in Japan. Occurrence of D. anglica and Nup. pumilum var. ozense is another interesting issue of phytogeography in relation to geological-climatic changes of Japan in the past. The drainage and cultivation of the surrounding area and controlled canalization of the systems have been affecting on this Mire. Agricultural utilizations of the Sphagnum peats for land amelioration have been bringing forth the damages of the natural Sphagnetea as well. The abovementioned is a conclusion stated by Ito et al. in 1969, thirty years ago. However, Sarobetsu Mire has been realized as a precious asset by tourists as well as inhabitants, and conservational status of this Mire seems to be strengthened more and more than that 30 years ago.

(A part of the prerent paper was presented at the 2nd International Wetlands Conference, 13-23 June, 1984, Trebone, Czechoslovakia.)

\section{Appendix I}

\section{A list of conservational species* on Sarobetsu Mire}

I. Bryophyta

$$
\text { A. Musci }
$$

\section{Sphagnaceae}

Sphagnum cuspidatum Hoffm. Harimizugoke

Sph. fallax (Klinggr.) Klinggr. (=Sph. apiculatum H. Lindb.)

$\begin{array}{ll} & \text { Sankakumizugoke } \\ \text { Sph. fuscum (Schimp.) Klinggr. } & \text { Chamizugoke } \\ \text { Sph. magellanicum Brid. } & \text { Murasakimizugoke }\end{array}$

Sph. nemoreum Scop. (=Sph. capillaceum (Weiss.) Schrank)

Sph. palustre L.

Sugibamizugoke

Sph. papillosum Lidb.

Ōmizugoke

Ibomizugoke 
Sph. pulchrum (Braithw.) Warnst.

Utsukushimizugoke

Sph. riparium Aongstr.

II. Pteridophyta

2. Lycopodiaceae

Lycopodium inundatum L.

III. Spermatophyta
B. Gymnospermae

3. Pinaceae

Picea glehnii (Fr. Schm.) Masters

C. Angiospermae

a. Dicotyledoneae

i. Choripetalae

4. Nymphaeaceae

Nuphar pumilum var. ozense (Miki) Hara

5. Droseraceae

Drosera anglica Hudson

D. rotundifolia L.

6. Rosaceae

Rubus chamaemorus L.

7. Empetraceae

Empetrum nigrum var. japonicum K. Koch

8. Violaceae

Viola kamtschadalorum W. Becker et Hulten

ii. Sympetalae

9. Ericaceae

Andromeda polifolia L.

Chamaedaphne calyculata (L.) Moench.

Vaccinium oxycoccus L.

10. Primulaceae

Trientalis europaea L.

11. Gentianaceae

Gentiana triflora var. horomuiensis (Kudo) Hara

Menyanthes trifoliata $\mathrm{L}$.

12. Lentibulariaceae

Utricularia intermedia Hayne

Utr. vulgaris var. japonica Makino

b. Monocotyledoneae

13. Scheuchzeriaceae

Scheuchzeria palustris L.

14. Poaceae

Moliniopsis japonica (Hack.) Hayata

15. Cyperaceae
Akaezomatsu

Ozekōhone

Nagabamosengoke

Mōsengoke

Horomuiichigo

Ganköran

Ōbatachitsubosumire

Himeshakunage

Yachitsutsuji

Tsurukokemomo

Tsumatoriso

Horomuirindo

Mitsugashiwa

Kotanukimo

Tanukimo

Horomuisō

Numagaya 
Eleocharis margaritacea (Hult.) Miyabe et Kudo

Rhynchospora fauriei Franch.

Shirominoharii

Oinunohanahige

16. Araceae

Calla palustris L.

Himekaiu

17. Eriocaulaceae

Eriocaulon monococon var. confusum Ko. Ito

Sarobetsuhoshikusa

18. Liliaceae

Heloniopsis orientalis (Thunb.) C. Tanaka

Shōjyōbakama

Hemerocallis esculenta Koidz.

Zenteika

Veratrum stamineum Maxim.

Kobaikeiso

\section{Iridaceae}

Iris laevigata Fisch.

Kakitsubata

20. Orchidaceae

Amitostigma kinoshitae (Makino) Schltr.

Koanichidori

Dactylostalix ringens Reich. fil.

Ichōran

Eleorchis japonica (A. Gray) F. Maekawa

Sawaran

Ephippianthus schmidtii Reich. fil.

Koichoran

Epipactis papillosa Fr. et Sav.

Ezosuzuran

Ep. thunbergii A. Gray

Kakiran

Goodyera foliosa var. laevis Finet

Akebonoshusuran

Gymnadenia camtschatica (Cham.) Miyae et Kudo

Nobinechidori

Habenaris linearifolia Maxim.

Ōmizutonbo

Hab. yezoensis var. longicalcarata Miyabe et Tatewaki

Ozenosawatonbo

Liparis kumokiri F. Maekawa

Kumokirisō

Listera cordata (L.) R. Br.

Futabaran

Myrmechis japonica (Reich. Fil.) Rolfe

Aridōshiran

Oreorchis patens (Lindl.) Lindl.

Kokeiran

Platanthera hologlottis Maxim.

Mizuchidori

Plath. tipuloides var. nippoica (Makino) Ohwi

Kobanotonbosō

Pogonia japonica Reich. fil.

Tokisō

Spiranthes sinensis (Pers.) Ames

Nejibana

* Here, conservational species mean the species which are considered to be protected from the threat of extinction and to be designed their preservation and maintenance in fields.

Nomenclature : Iwatsuki and Mizutani (1974), Nakaike (1982), Ohwi and Kitagawa (1983), Smith (1978), Suzuki (1972), and Watson (1981). 


\section{Appendix II}

\section{Terminology}

It has been offered to define a Japanese word "Shitsugen" that it now occurs in northern Japan, especially in Hokkaido, where the climate is too cold for forests to be formed in wetlands $\cdots \cdot \cdot$, and that it usually accompanies peat and is equivalent to German "Moor" (Kushiro Shitsugen National Park Office, Nature Conservation Bureau, Environmental Agency, 1989). This concept of Shitsugen may be available to conveniently an explanation about the so-called wetland, because there are various kinds of vegetation types in combination with genesis, species composition, gomorphology, landscape, etc. and it is very difficult for people to understand properly what is a bog, what is a marsh, etc.

In the present paper, we use several words or terms about wetland vegetation, so that we would like to show our concept of those terms.

The term wetland is used here in a broad sense, covering several types of ecosystems characterized by permanent or prolonged waterlogging, namely bogs, fens, marshes, swamp forests, and mangrove forests. The definition of bog, fen, swamp forests and marsh follows principally that given by Gore (1983), and Zoltai and Pollet (1983).

Bogs are peat-covered areas or peat-filled depressions with a high water table and a surface carpet of mosses, chiefly Sphagnum spp. The mosses often form raised hummocks, separated below wet interstices. The bog surface is often raised, or, if flat or level with the surrounding wetlands, it is virtually isolated from mineral soil waters. Trees may or may not be present in bogs, and they are frequently characterized by a layer of ericaceous shrubs. It is very often to use the term "Moss". Moss is used here synonymously for bog, which is the wet acid peat vegetation, but is used somewhat strictly in a sense of syntaxonomy. Tansley (1965) stated that "Moss" has the additional advantage of linguistic correspondence with the Scandinavian words Mosse (Swedish), Mose (Danish and Norwegian) and the German Moos, which are applied to just the same vegetation, although it has the drawback - not perphaps very serious - of possible confusion with taxonomic group of Musci. There is a disadvantage of the term "bog" as Tansley (op. cit.) pointed out that it is sometimes loosely used in common language for any wet soil into the foot sinks, (but not a very serious drawback).

Fens are peatlands characterized by surface layers of poorly to moderately decomposed peat, often with well-decomposed peat near the base. They are developed in a poorly drained areas under the influence of waters derived from outside, and, in the course of transport, enriched with dissolved compounds. In comparison with European fens, it may be emphasized the alkaline character, but it is not necessarily to be alkaline. "Fen is somewhat or decidedly alkaline, nearly neutral or somewhat, but not extremely acid" (Tansley, op. cit.). For all types of bogs and fens a collective name "mires" is applied (Moore and Bellamy, 1974 ; Gore, op. cit.), and it has been used by Ito since 1969 (Ito et al., 1969) in Japan.

Swamps are wooded wetlands (peatlands and mineral wetlands) where standing to gently flowing waters occur seasonally or persist for long period on the surface. Frequently there is an abundance of pools and channels indicating surface water flow. The substrate 
is usually continually waterlogged, and it consists of mixtures of transported mineral and organic sediments, or peat deposited in situ.

Marshes are grassy, wet mineral soil areas, periodically inundated to a depth of $2 \mathrm{~m}$ or less, with standing or slowly moving water (Zoltai and Pollet, 1983). Surface water levels may fluctuate seasonally, with declining levels exposing drawdown zones of matted vagetation or mudflats. Marshes are subject to a gravitational water table, but water remains within the rooting zone of plants during at least part of the growing season. The substratum usually consists of mineral and organic soils with a high mineral content, but there is a little peat accumulation. Marshes characteristically show zonal or mosaic surface pattern of vegetation, consisting of unconsolidated grass and sedge sods, frequently interspersed with chanells or pools of open water.

\section{References}

Ellenberg, H. (1955) : Grundlage der Vegetationsgliederung. I Teil : Aufgeben und Methoden der Vegetationskunde. 136 pp. In Walter, H. (ed.), Einfuhrung in der Phytology IV. Eugen Ulmer. Stuttgart.

Goodall, E. W. (1983) : Conclusion - the future of mire. In Gore, A. J. P. (ed.), Mires : Swamp, bog, fen and moor. Ecosystems of the World 4B. 395-396. Elsevier. Amsterdam, Oxford, New York.

Gore, A. J. P. (1983) : Introduction. In Gore A. J. P. (ed.), Mires : Swamp, bog, fen and moor. Ecosystems of the World 4A. 1-34. Elsevier. Amsterdam, Oxford, New York.

Hokkaido Agricultural Experiment Station (1936) : Annual Report of Hokkaido Agricultural Experiment Station*. 292 pp. Hokkaido Agricultural Experimental Station.

Hokkaido Development Agency (1963) : Report of the undeveloped peatlands of Hokkaido*. 315 pp. Hokkaido Development Agency.

Ito, K. (1983) : Man's impact on the wetlands in Japan. In Holzner, M. J. A. Werger and I. Ikushima (eds.), Man's impact on vegetation. 327-334. Dr. W. Junk Pub. The Hague, Boston, London.

Ito, K., M. Shimizu and M. Koga (1982) : Ecosystems of Hokkaido. Map in Scale 1:6,000,000 based on LANDSAT images**. Japan Foundation for Shipbuilding Advancement. Tokyo.

Ito, K. and H. Tachibana (1987) : Flora and vegetation of Ukijima mire. Conservation flora of Hokkaido 2. Environ. Sci. Hokkaido $10: 81-93$.

Ito, K., M. Tohyama, K. Ishizuka and T. Tsujii (1969) : The mire vegetation of Sarobetsu. 1-5. Ann. Rep. JIBP-CT(P) for Fisc. Yr. 1968. Types and Conservation of Terr. Pl. Com. Jap. Sendai.

Iwatsuki, Z. and M. Mizutani (1974) : Coloured Illustrations of Bryophytes of Japan (Hattori, S. ed.).* viii + 405. Hoikusha. Osaka.

Jasnowski, M. (1977) : Extents and directions of changes of plant cover of the bogs. Phytocoenosis $1: 193$ $-209$.

Kashimura, T. and H. Tachibana (1982) : The vegetation of the Ozegahara moor and its conservation. In Hara, H. (ed.), Ozegahara : Sci. Rep. of the Highmoor in Central Japan. 193-224. Japan Society for the Promotion of Science. Tokyo.

Kushiro Shitsugen National Park Office (1989) : Kushiro Shitsugen as designated under the Article 2 of the Ramsar Convention. 24 pp. Envrionmental Agency.

Miyawaki, A., S. Okuda, K. Fujiwara and K. Inoue (1977) : Vegetation der Sarobetsu-genya NOHokkaidos***. 47 pp. 1 map, 10 Table sheets. The Tourist Resources Conservation Foundation. Tokyo.

Moore, P. D. and D. J. Bellamy (1976) : Peatlands. 2 nd ed. 221 pp. Elek Science. London.

Mueller-Domboi, D. and H. Ellenberg (1974) : Aims and methods of vegetation ecology III Vegetation analysis in the field. $45-547$. J. Willy \& Sons Inc. New York. 
Ohwi, J. and M. Kitagawa (1983) : New Flora of Japan Phanerogams*. 1716 pp. Shibihdo. Tokyo.

Nakaike, T. (1982) : New Flora of Japan Pteridophyta*. 808 pp. Shibundo. Tokto.

Numata, M. et al. (eds.) (1989) : A Red-Data book of plant species to be protected in Japan*. 320 pp. Japan Nature Conservation Association. Tokyo.

Sakaguchi, Y. (1979) : Distribution and genesis of Japanese peatlands. Bull. Geography Tokyo Univ. 11 : $17-42$.

Sheail, J. and T. C. E. Wells (1983) : The fenlands of Huntingdonshire, England : a case study in catastrophic change. In A. J. P. Gore (ed.), Mires : Swamp, bog, fen and moor. Ecosystems of the World 4B. 375-393. Elseveier. Amsterdam, Oxford, New York.

Smith, A. J. E. (1978) : The Moss flora of Britain and Island. vii + 706. Cambridge Univ. Press. Cambridge, London, New York, Melbourne.

Suzuki, H. (1972) : Distribution of Sphagnum species in Japan and attempt to classify the moss basing on their combination. J. Hattori Bot. Lab. No. 35, 1-24.

Tachibana, H. (1969) : Vegetation changes of a moor in Mts. Hakkoda caused by human treading. Ecol. Rev. $17: 177-188$.

Tachibana, H. (1976) : Changes and revegetation in Sphagnum moors destroyed by human treading. Ibid. $18: 133-210$.

Tachibana, H. (1977) : Moor vegetation and human impacts. In Ishizuka, K. (ed.) Plant Ecology I : the distribution and environment of communities. $346-355^{*}$. Asakura Shoten. Tokyo.

Tachibana, H. and K. Ito (1980) : Phytosociological studies of the Sarobetsu mire in the northern part of Hokkaido, Japan**. Environ. Sci. Hokkaido 3 : 73-134.

Tachibana, H., T. Takanashi and Y. Ozaki (1988): Changes of bog vegetation and soil conditions of Ukijima mire induced by human treading**. Rep. Taisetsuzan Inst. Sci. No. 23, 37-55.

Takakuwa, J. and K. Ito (1986) : Ecological aspects of Sasa in mires**. Mem. Environ. Sci. Hokkaido Univ., Sapporo. No. 2, 47-65.

Tansley, A. G. (1965) : The British Islands and their vegetation. 4 th Impr. II. xxvii +485-930. Cambridge Univ. Press.

Tatewaki, M. (1954) : Phytogeographical studies on Orchidaceae in the islands of the North Pacific. Act. Hor. Gotob. $19: 51-112$.

Terasmae, J. (1977) : Postglacial history of Canadian muskeg. In Radforth, N. W. and C. O. Brawner (eds.), Muskeg and the northern environment in Canada. 9-30. Univ. Toronte Press. Tronto, Buffalo.

Tsujii, T. (1963) : See Hokkaido Development Agency.

Watson, E. V. (1981) : British Mosses and Liverworts. 3 rd ed. xviii +519 . Cambridge Univ. Press. Cambridge, London, New York, New Rochelle, Melbourne, Sydney.

Wolejko, L. (1983) : The sedge Carex chordorrhiza and other rarities in the plant cover of the "Morzyslaw Maly" nature reserve in the Drawski Landscape Park. Chr. Przyr. Ojcz. 39 : 5-14.

Wolejko, L. and K. Ito (1986): Mires of Japan in relation to mire zone, volcanic activity and water chemistry. Jap. J. Ecol. 35 : 575-586.

Yano, Y., T. Akazawa and Y. Umeda (1980) : Present status and problems for agricultural use of peat-land in Hokkaido, northern Japan. Proc. 6 th Int. Peat Congr., Duluth, 1980. 501-505.

Zoltai, S. C. and F. C. Pollett (1983) : Wetlands in Canada : Their classification, distribution, and use. In Gore, A. J. P. (ed.), Mires : swamp, bog, fen and moor. Ecosustems of the World 4B. 245-268. Elsevier. Amsterdam, Oxford, New York.

* in Japanese $\quad * *$ in Japanese with English summary or with English translation of Figures and Tables $* * *$ in Japanese with German summary 